Anjarsari I.R.D.

\title{
Katekin teh Indonesia : prospek dan manfaatnya
}

\section{Indonesia tea catechin : prospect and benefits}

Diterima : 15 Juli 2016/Disetujui : 10 Agustus 2016 / Dipublikasikan : 30 Agustus 2016

CDepartment of Crop Science, Padjadjaran University

\begin{abstract}
Indonesia tea is known for having catechin content (natural antioxidants) is the highest in the world. Catechins are a derivative of poliphenol which have high antioxidant properties. Factor that affecting the levels of catechins are tea varieties and clones, altitude, age of leaves, and plucking type. Considered from the standpoint of health, the higher catechin mean more beneficial to health. But otherwise, in terms of the taste, has a reverse ratio. Catechins, also plays an important role in determining the flavour and flavor. Bitter taste from tea is strongly influenced by these substances. It means that the higher catechin, will lead to higher the bitterness. Catechins are colorless compound, soluble in water, carrying of bitter taste and astringent properties in steeping tea. The compound is the most important thing in tea leaves because it can determine the quality in tea processed. Catechin in tea are complex compounds composed of epicatechin (EC), epicatechin gallate (ECG), epigallocatechin (EGC), epigallocatechin gallate (EGCG), and galokatekin (GC). The dominant component namely epigallocatechin, and epigallocatechin gallate. Catechin tea is the main substance that causes tea qualify as functional beverages, content ranges between $20-30 \%$ of the dry weight of the leaves. In the processing, directly or indirectly, catechins change is always associated with all properties of tea included the taste, color and flavour.
\end{abstract}

Keywords: Catechin · Poliphenol · Functional beverages

Sari Teh Indonesia dikenal karena memiliki kandungan katekin (antioksidan alami) tertinggi di dunia Katekin adalah salah satu turunan dari poliphenol yang memiliki khasiat antioxidant yang tinggi. Faktor yang mempengaruhi kadar katekin adalah varietas dan klon teh, ketinggian tempat,

\footnotetext{
Dikomunikasikan oleh Tati Nurmala

Anjarsari I.R.D.

Padjadjaran University Doctoral Student, Agricultural

Faculty, UNPAD Jatinangor, West Java, Indonesia

Korespondensi: intan.ratna@unpad.ac.id
}

umur daun, serta jenis petikan. Dipandang dari sisi kesehatan, makin tinggi katekin berarti makin bermanfaat buat kesehatan. Akan tetapi sebaliknya, ditinjau dari sisi rasa, memiliki perbandingan yang terbalik. Katekin berperan penting di dalam menentukan aroma dan rasa. Katekin merupakan senyawa tidak berwarna dan larut dalam air serta membawa sifat pahit dan sepat pada seduhan teh. Senyawa ini paling penting dalam daun teh karena dapat menentukan kualitas teh dalam pengolahanya. Katekin dalam teh merupakan senyawa kompleks yang tersusun atas epikatekin (EC), epikatekin galat (ECG), epigalokatekin (EGC), epigalokatekin galat (EGCG), dan galokatekin (GC). Komponen yang mendominasi yaitu epigalokatekin dan epigalokatekin galat. Kandungan katekin berkisar antara 20-30\% dari seluruh berat kering daun. Dalam pengolahan, secara langsung atau tidak langsung, perubahan katekin selalu dihubungkan dengan semua sifat teh jadi, yaitu rasa, warna, dan aroma. Katekin yang mendominasi $20 \%$ berat kering teh merupakan substansi utama yang menyebabkan teh memenuhi persyaratan sebagai minuman fungsional

Kata kunci : Katekin · Poliphenol · Minuman fungsional

\section{Pendahuluan}

Teh di Indonesia. Perkebunan sebagai salah satu sub sektor pertanian, memiliki peran yang cukup penting dalam pembangunan pertanian Indonesia. Perkebunan teh merupakan salah satu bentuk perkebunan yang sudah lama dibudidayakan di Indonesia. Teh adalah bahan minuman penyegar yang sudah lama dikenal dan sudah membudaya dalam kehidupan masyarakat Indonesia. Beberapa kandungan senyawa kimia dalam teh dapat memberi kesan warna, rasa dan aroma yang memuaskan peminumnya. Sehingga sampai saat ini, teh adalah salah satu minuman penyegar yang banyak diminati. Selain sebagai bahan minuman, 
teh juga banyak dimanfaatkan untuk obat-obatan dan kosmetika (Diah Indarti, 2015) Selain sebagai produsen, Indonesia juga merupakan negara eksportir teh pada urutan kelima di dunia dari segi volume setelah Sri Lanka, Kenya Cina dan India.

Perkembangan produktivitas teh di Indonesia selama tahun 2003-2014 cenderung berfluktuasi. Produktivitas teh nasional tertinggi terjadi pada tahun 2009 sebesar $1.571 \mathrm{~kg} / \mathrm{ha}$, namun pada tahun 2010 menurun menjadi $1.533 \mathrm{~kg} / \mathrm{ha}$ dan pada tahun 2014 menjadi $1.464 \mathrm{~kg} / \mathrm{ha}$ (Direktorat Jenderal Perkebunan, 2014) Pola perkembangan produksi teh nasional serupa dengan pola perkembangan produksi teh PBN. Hal ini tidak luput dari besarnya kontribusi produksi teh dari PBN terhadap produksi teh nasional walaupun kontribusinya semakin meningkat. Sementara itu perkembangan produksi teh yang berasal dari PR dan PBS juga cenderung meningkat demikian juga dengan kontribusinya. Berdasarkan kontribusinya selama tahun 2010-2014, PBN menguasai 42,41\% total produksi teh Indonesia, diikuti oleh PR dengan kontribusi sebesar 34,64\% dan PBS sebesar 22,95\% Pada tahun 2012 terjadi penurunan konsumsi teh per kapita per tahun yang cukup signifikan, konsumsi per kapita pada tahun tersebut sebesar $0,52 \mathrm{~kg} /$ tahun. Agar tidak terjadi penurunan konsumsi terus menerus maka pemerintah mengambil tindakan dengan melakukan promosi teh di dalam negeri yang berguna untuk mendongkrak tingkat konsumsi masyarakat untuk minum teh. Pada tahun 2014 konsumsi teh di Indonesia mengalami peningkatan sebesar 0,61 $\mathrm{kg} / \mathrm{kapita} /$ tahun, dalam hal ini upaya pemerintah berhasil (Sekjen Kementan, 2015)

Katekin Penentu Kualitas Perdagangan. Teh Indonesia dikenal karena memiliki kandungan katekin (antioksidan alami) tertinggi di dunia. Kebanyakan produksi teh Indonesia adalah teh hitam, diikuti oleh teh hijau (http://www.indonesia-investments.com, 2015). Katekin merupakan salah satu bentuk metabolit sekunder yang terkandung dalam daun teh. Metabolit sekunder merupakan senyawa yang dihasilkan atau disintesa pada sel dan group taksonomi tertentu pada tingkat pertumbuhan atau stress tertentu. Senyawa metabolit sekunder memiliki struktur yang lebih komplek dan sulit disintesa, jarang dijumpai di pasaran karena masih sedikit (15\%) yang telah berhasil diisolasi sehingga memiliki nilai ekonomi tinggi (mahal harganya).

Katekin merupakan salah satu senyawa utama dari substansi teh hijau dan paling berpengaruh terhadap mutu daun teh. Dalam pengolahannya, senyawa tidak berwarna ini, baik langsung maupun tidak langsung selalu dihubungkan dengan semua sifat produk teh. yaitu rasa, warna dan aroma. Tabel 1 adalah gambaran kadar katekin pada beberapa jenis teh di beberapa produsen teh.

Tabel 1. Katekin pada Beberapa Jenis Teh Berdasarkan Negara Penghasil.

\begin{tabular}{llc}
\hline \hline Negara & \multicolumn{1}{c}{ Jenis Teh } & $\begin{array}{c}\text { Substansi } \\
\text { katekin (\% b.k) }\end{array}$ \\
\hline Indonesia & Teh hitam & 8,24 \\
& ortodox & \\
& Teh hitam CTC & 7,02 \\
& Teh hijau ekspor & 11,60 \\
& Teh hijau lokal & 10,61 \\
Jepang & Teh wangi & 9,28 \\
Cina & Sencha & 5,06 \\
& Teh oolong & 6,73 \\
Sri lanka & Teh wangi & 7,47 \\
\hline \hline
\end{tabular}

Sumber : (Bambang et al. , 1995)

Faktor yang mempengaruhi kadar katekin adalah varietas dan klon teh, ketinggian tempat, waktu panen teh. Pucuk pertama daun teh, kandungan katekinnya lebih tinggi dibanding daun teh yang lainnya. Begitu juga waktu panen. Teh Jepang yang dipanen pertama kandungan katekinnya paling rendah dibanding dengan panen-panen pada bulan berikutnya, kecuali untuk teh putih, teh ini memiliki kandungan katekin yang paling tinggi, karena selain mengalami proses yang sangat singkat, daun yang digunakan adalah pucuk daun yang benar-benar sangat muda (peko saja). Pada Tabel 2 berikut ini menggambarkan kandungan katekin yang terdegradasi pada pengolahan teh oolong, teh hijau dan teh hitam.

Tabel 2. Senyawa Katekin yang Terdegradasi pada Pengolahan Berbagai Jenis Teh.

\begin{tabular}{lccc}
\hline \multicolumn{1}{c}{ Jenis Teh } & $\begin{array}{c}\text { Kandungan katekin } \\
\text { sebelum pengolahan }(\%)\end{array}$ & $\begin{array}{c}\text { Kandungan katekin } \\
\text { setelah pengolahan }(\%)\end{array}$ & $\begin{array}{c}\text { Katekin terdegradasi } \\
\text { dalam pengolahan (\%) }\end{array}$ \\
\hline Teh oolong & 13,76 & 9,49 & 31,03 \\
Teh hijau & 13,76 & 10,04 & 27,03 \\
Teh hitam & 13,76 & 5,91 & 57,70 \\
\hline \hline
\end{tabular}

Sumber : Karori et al (2007) 
Dilihat dati Tabel 2 diatas, tampak jelas bahwa kadar katekin teh hijau masih di atas kadar katekin teh hitam. Khasiat yang dimiliki oleh teh berasal dari kandungan senyawa kimia yang terdapat dalam daun teh. Senyawa kimia yang terkandung dalam daun teh terdiri dari empat kelompok besar yaitu golongan fenol, bukan fenol, aromatis dan enzim. Keempat kelompok senyawa kimia tersebut bersamasama mendukung terjadinya sifat-sifat yang baik pada seduhan daun teh, apabila pengendaliannya selama pengolahan dapat dilakukan dengan tepat. Katekin merupakan kelompok terbesar dari komponen daun teh, terutama kelompok katekin flavanol.

Gambar 1 adalah rumus bangun katekin, sedangkan Gambar 2 menjelaskan jalur biosintesis katekin.

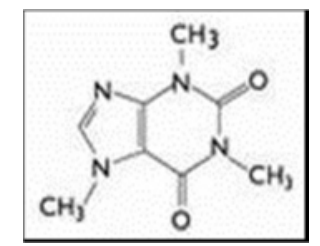

Gambar 1. Rumus Bangun Katekin.

Katekin tersintesis dalam daun teh melalui empat jalur yaitu isoprene pathway, polyketide pathway, shikimate pathway, dan amino acid pathway. Sebagian besar flavanoins/polyphenol di daun teh terdiri atas katekin seperti epicatechin (EC), epigallocatechin (EGC), epicatechin gallate (ECG) dan epigallocachin gallate (EGCG). Epicatechin (EC) dan epigallocatechin (EGC) memunculkan rasa sedikit sepet (pahit) dengan sedikit manis setelah diminum, sedangkan bentuk gallatenya (EGC dan EGCG) memunculkan rasa sepet yang kuat (Yamanishi, 1991 dalam Mitrowihardjo, 2012).Senyawasenyawa katekin tersebut mempunyai manfaat karena sifatnya dalam meniadakan bau, sebagai antioxidant berkemampuan untuk menghambat pertumbuhan jamur, tumor dan virus.

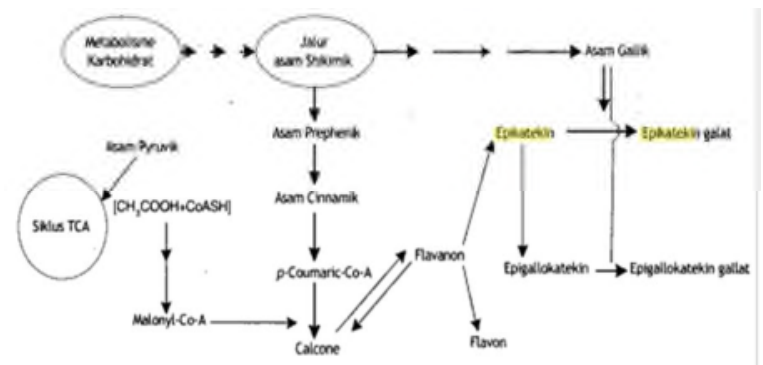

Gambar 2. Jalur Biosintesis Katekin.

(Sumber : Nakabayashi, 1991 dan Syah, 2006)
Kafein merupakan senyawa purin alkaloid, juga merupakan komponen penting dalam menentukan citarasa teh terutama rasa pahit/ sepetnya. Tetapi karena sifat pharmatologi dari kafein yang merangsang sistem syaraf sentral, kafein yang tinggi pada daun teh kurang diinginkan (Takeda, 1994 dalam Mitrowihardjo, 2012). Kandungan katekin mencapai 30\% dari berat kering, sedangkan kandungan kafein hanya $5 \%$ dari berat kering (Graham, 1992). Dalam pembuatan teh hitam daun harus dipecah menjadi bagian-bagian kecil. Hal ini memungkinkan sito-plasmik polifenol oksidase untuk mengoksidasi flavan-3-ols di vakuola. Akibat utama dari proses enzim oksidasi ini, secara resmi dikenal sebagai proses fermentasi, adalah polimerisasi dari mono-mer flavan-3-ol untuk bentuk thearubigins (TRs) dan theaflavins (TFs). Zat kimia yang terkandung dalam TRs belum diketahui dan sulit untuk dianalisis (Whitehead and Temple, 1992). Sedangkan TFs sangat berkorelasi dengan kualitas teh. Seperti dijelaskan oleh Owour dan Obanda (1995), bahwa theaflavins digallat sangat penting untuk memprediksi kualitas teh hitam di Kenya. Konsentrasi katekin sangat tergantung umur daun. Pucuk dan daun pertama paling kaya katekin galat. Kadar katekin bervariasi tergantung pada varietas tanaman tehnya (Andi Nur Alam Syah, 2006).

Oksidasi enzimatis daun teh segar menginduksi terjadinya enzymatic oxidation flavan-3-ol (katekin) menghasilkan dua pigmen utama dalam teh hitam yaitu theaflavin (TF) dan thearubigin (TR). Theaflavin terdiri atas empat jenis yaitu nongallated theaflavin (TF), mono-gallated theaflavin (TF-3g dan TF-3'g), dan digallated theaflavin (TF-3,3'dg) (Menet et al., 2004 cit Mitrowihardjo, 2012). Keberadaan theaflavin dalam teh hitam akan ditentukan oleh komposisi flavan-3-ol (katekin) pada pucuk daun teh yang diolah (Wright et al., 2002 dalam Mitrowihardjo, 2012). Perubahan dari flavan-3-ol (katekin) menjadi theaflavin (TF) dapat dilihat pada Tabel 3 berikut ini.

Tabel 3 . Komponen Utama Theaflavin.

\begin{tabular}{|c|c|c|}
\hline Precursor A & Precursor B & Product \\
\hline Epicatechin & Epigallocatechin & Theaflavin \\
\hline Epicatechin & $\begin{array}{l}\text { Epigallocatechin } \\
\text { gallate }\end{array}$ & $\begin{array}{l}\text { Theaflavin-3 } \\
\text { gallate }\end{array}$ \\
\hline $\begin{array}{l}\text { Epicatechin } \\
\text { gallate }\end{array}$ & Epigallocatechin & $\begin{array}{l}\text { Theaflavin- } 3 \text { ' } \\
\text { gallate }\end{array}$ \\
\hline $\begin{array}{l}\text { Epicatechin } \\
\text { gallate }\end{array}$ & $\begin{array}{l}\text { Epigallocatechin } \\
\text { gallate }\end{array}$ & $\begin{array}{l}\text { Theaflavin - } \\
3,3^{\prime} \text { gallate }\end{array}$ \\
\hline
\end{tabular}

Sumber : Hilal and Engelhardt (2007). 
Theaflavin banyak dikaitkan dengan kualitas karena pengaruhnya pada astringency, brightness dan briskness, sedang thearubigin terkait dengan kualitas karena kontribusinya pada warna, kekuatan (strength), dan rasa di mulut (mouthfell) (Sud and Asha, 2000)

\section{Teknologi Budidaya untuk Meningkatkan Katekin dalam Teh}

Kadar katekin dalam daun teh sanagt dipengaruhi oleh banyak faktor, diantaranya jenis varietas dan klon teh, ketinggian tempat dimana pucuk dihasilkan, pengaruh petikan, serta proses selama pengolahan di pabrik.

Varietas dan klon teh. Kandungan katekin pada pucuk teh varietas Assamica lebih banyak dibandingkan dengan varietas sinensis (Andi Nur Alam Syah 2006) Namun varietas sinensis memiliki aroma lebih baik karena kandungan asam aminonya lebih tinggi. Tanaman teh yang dibudidayakan di Indonesia hampir 100\% merupakan varietas Assamica

Tabel 6. Kandungan Katekin pada Pucuk Teh (Camellia sinensis) Varietas Assamica dan Varietas Sinensis.

\begin{tabular}{lllllll}
\hline \hline Varietas & \multicolumn{5}{c}{ Katekin (\%) } & Katekin \\
\cline { 2 - 6 } & C & EC & EGC & ECG & EGCG & Total \\
\hline Assamica & 0,02 & 1,44 & 0,35 & 0,35 & 12,10 & 17,26 \\
Sinensis & 0,07 & 1,13 & 2,38 & 2,38 & 8,59 & 13,52 \\
\hline \hline
\end{tabular}

Sumber : Yamamoto et al. 1997

Teh hijau dari klon berdaun sempit (C. sinensis var. sinensis) menunjukkan epigallocatechin gallate (EGCG) dan epigallocatechin (EGC) yang tinggi, sedang teh hijau dari klon berdaun lebar (C. sinensis var assamica) menunjukkan epicatechin gallate (ECG) dan epicatechin (EC) yang tinggi (Zhonghua et al., 1995 dalam Mitrowihardjo, 2012). Hal yang berbeda dilaporkan oleh Nakagawa (1970) bahwa klon yang biasa digunakan untuk memproduksi teh hitam (klon berdaun lebar) kaya akan kandungan katekin terutama ECG dan EGCG (bentuk gallatenya). Kandungan dengan flavanoid yang tinggi dan kafein redah sangat diperlukan dalam pemuliaan tanaman teh. Kultivar teh dengan flavanoid tinggi banyak ditemukan dari $C$. sinensis var assamica yang umumnya ditanam di India, namun kafein juga tinggi. Kultivar dari Jepang yang umumnya merupakan hibrid dari $C$. sinensis var assamica dan C. sinensis var. sinensis menunjukkan kandungan kafein yang rendah, tetapi kandungan flavanoidnyanya juga rendah (Takeda, 1994). Pada kebun Pagilaran, beberapa klon telah diuji kandungan katekinnya guna menduga mutu dari klon teh tersebut.Total katekin klon GMB 9, PGL 10, TRI 2025 lebih tinggi dibanding dengan klon yang laindi lokasi dengan ketinggian 1346 mdpl, sedangkan klon PGL 15, GMB 9 lebih tinggi dibanding dengan klon yang lain di lokasi dengan ketinggian 889-925 m dpl. Mutu teh berkorelasi sangat nyata dengan berat peko per petak, jumlah peko per tanaman, berat pucuk peko dan burung per petak dan berkorelasi nyata dengan rasa (Mitrowihardjo, 2012).

Ketinggian tempat. Intensitas sinar matahari dan suhu berpengaruh terhadap pertumbuhan pucuk, sehingga semakin tinggi tempat teh dibudidayakan diperkirakan pertumbuhan pucuk semakin lambat dan total katekin semakin bertambah. Logika tersebut sejalan dengan hasil penelitian yang dilakukan oleh Mahanta dan Baruah (1988) bahwa perbedaan ekosistem (ketinggian) cenderung berpengaruh terhadap kualitas teh utamanya aroma, namun demikian tidak terlalu nyata berbeda. Kondisi iklim untuk pertumbuhan teh yang baik di Jepang adalah suhu rata-rata sepanjang tahun $11,5^{\circ}-18,0^{\circ} \mathrm{C}$ dengan rerata hujan $1.500-2.000$ $\mathrm{mm}$ per tahun. Umumnya hasilnya tinggi di wilayah dengan suhu lebih dari $16{ }^{\circ} \mathrm{C}$, dan rendah di wilayah dengan temperatur kurang dari $14^{\circ} \mathrm{C}$, sedang kualitas mempunyai tendensi yang berkebalikan dengan hasil tadi (Hara, 1999). Hara (1999) menyatakan bahwa umumnya hasil teh tinggi di wilayah dengan suhu lebih dari $16{ }^{\circ} \mathrm{C}$ dan rendah di wilayah dengan suhu kurang dari $14{ }^{\circ} \mathrm{C}$, sedang kualitas mempunyai tendensi yang berkebalikan dengan hasil tadi. Dapat diartikan bahwa bahwa hasil teh akan tinggi di lokasi yang rendah, dan hasil teh akan rendah pada lokasi yang tinggi, sedang kualitas teh (katekin) mempunyai tendensi yang berkebalikan dengan hasil teh tersebut. Hasil penelitian Santoso dkk. (2009), bahwa kisaran total katekin GMB 1 sampai dengan GMB 11 yang ditanam di Gambung berkisar antara 13,9 sampai dengan $17,1 \%$ berat kering, sedang total katekin TRI 2025 adalah 15,7 \% berat kering. Besar kemungkinan perbedaan pengelolaan tanaman, kesuburan lahan, kondisi lingkungan, serta perbedaantinggi tempat berpengaruh terhadap total katekin yang dihasilkan

Umur daun. Semakin muda umur daun akan semakin tinggi pula kadar katekinnya. 
Artinya bagian pucuk peko memiliki kandungan katekin tertinggi dibandingan daun bagian bawahnya. Sebagai gambaran dalam Tabel 1 berikut ini disajikan daftar kandungan zat katekin dan caffein pada bagian-bagian pucuk teh Indonesia

Tabel 1. Kandungan Katekin dan Kafein pada Bagian-bagian Pucuk Teh dalam \% Berat Kering

\begin{tabular}{lcc}
\hline \hline Bagian pucuk & Katekin(\%) & Kafein (\%) \\
\hline Peko & 26,5 & $4, .7$ \\
Daun pertama & 25,9 & 4.2 \\
Daun kedua & 20,7 & 3.5 \\
Daun ketiga & 17,1 & 2,9 \\
Tangkai atas & 11,7 & 2,5 \\
\hline \hline
\end{tabular}

Sumber : PPTK Gambung, 2006

Pengaruh Petikan terhadap mutu daun teh. Jenis pucuk yang dihasilkan sangat berpengaruh terhadap hasil teh. Semakin muda pucuk yang dipetik semakin tinggi kualitasnya. Menurut Pertumbuhan pucuk serta kandungan zat penentu mutu teh dipengaruhi oleh kondisi tanaman teh, kesuburan tanah, musim, umur tanaman teh setelah pangkas dan ketinggian tempat. Subarna (1990) menyatakan bahwa petikan kasar akan memberikan produksi lebih tinggi dengan mutu pucuk rendah, sedangkan petikan halus memberikan produksi lebih rendah dengan mutu pucuk tinggi. Namun, pada umumnya perkebunan teh lebih banyak mereapkan sistem petikan medium. Oleh karena itu petikan halus, medium dan kasar memberikan pengaruh terhadap mutu pucuk (persentase pucuk muda). Menurut Mitrowihardjo (2012), mutu berkorelasi nyata dengan rasa. Sekitar $50-60 \%$ mutu teh daun dipengaruhi oleh penampilan atau kenampakan teh setelah diolah dan kenampakan sangat dipengaruhi jumlah atau bobot peko yang ada.

Proses Pengolahan di Pabrik. Penurunan kandungan katekin terjadi selama proses pengolahan (teh hitam), hal ini disebabkan oleh terjadinya reaksi oksidasi senyawa katekin yang dikatalisa oleh enzim polifenol oksidase yang menghasilkan theaflavins dan thearubigins. Theaflavins dan thearubigins berpengaruh terhadap warna, aroma, kenampakan dan rasa pahit pada teh setelah diseduh. Polifenol dalam teh berupa katekin merupakan zat yang unik karena berbeda dengan katekin yang terdapat pada tanaman lain.

Penurunan kandungan katekin selama proses pengolahan teh hitam disebabkan oleh terjadinya reaksi oksidasi senyawa katekin yang dikatalisa oleh enzim polifenol oksidase.Proses oksidasi senyawa katekin sangat mudah terjadi karena enzim polifenol oksidase tersimpan dalam sitoplasma, sedangkan katekin ada dalam vakuola. Pemisah vakuola dan sitoplasma adalah sebuah membran yang disebut tonoplas. Membran tonoplas ini mampu mencegah pergerakan bebas substansi antara kedua bagian sel tersebut. Oksidasi senyawa katekin tidak terjadi dalam sel daun teh sampai enzim polifenoloksidase dan katekinnya terbawa masuk dan bertemu dengan percampuran isi sel tersebut.Sekali katekin bertemu dengan enzim polifenol oksidase, keduanya akan cepat teroksidasi oleh oksigen dari atmosfer. Pada Gambar 4 Menjelaskan letak polifenol dalam daun.

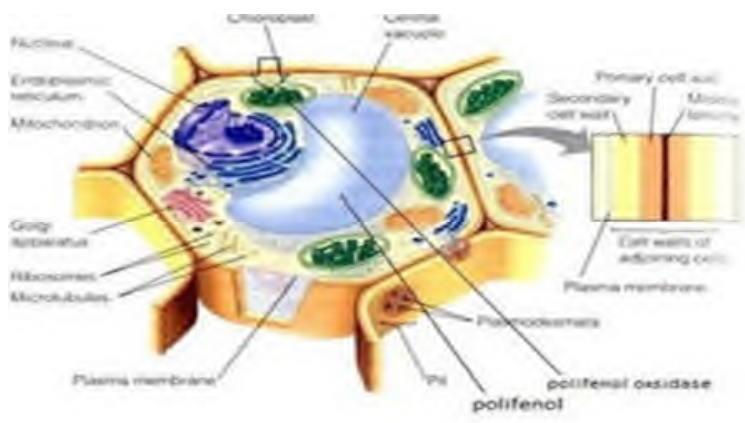

Gambar 4. Letak Polifenol dalam Daun.

Tabel 5. Komposisi Pucuk Daun Teh (\% Berat Kering)

\begin{tabular}{llll}
\hline \hline $\begin{array}{l}\text { Bagian dari } \\
\text { Sel }\end{array}$ & Senyawa & Total & $\begin{array}{l}\text { Yang Larut } \\
\text { dalam Air }\end{array}$ \\
\hline $\begin{array}{l}\text { Dinding sel } \\
\text { (cell wall) }\end{array}$ & $\begin{array}{l}\text { Seluluosa } \\
\text { Hemiselulosa }\end{array}$ & $\begin{array}{l}26,0 \\
\text { Lignin }\end{array}$ & 0,0 \\
& Pektin & - & - \\
Protoplasma & Protein & 17,0 & - \\
(outer cell & Lemak & 8,0 & - \\
membrane) & Tepung & 0,5 & 0,0 \\
Vakuola & Polifenol & 22,0 & 22,0 \\
(inner cell & /Katekin & & \\
membrane) & Kafein & 4,0 & 4,0 \\
& Asam amino & 7,0 & 7,0 \\
& Asam Gula & 3,0 & 3,0 \\
& Asam & 3,0 & 3,0 \\
& Organik & & \\
& Abu/mineral & 5,0 & 4,0 \\
& Jumlah & $\mathbf{1 0 0 , 0}$ & $\mathbf{4 5 , 3}$ \\
\hline \hline
\end{tabular}

Sumber : Bhatia, 1963 dalam Alamsyah, 2006

Teknologi proses pengolahan teh hijau yang ada saat ini belum didesain untuk menghasilkan teh hijau dengan kandungan katekin tinggi. Hasil kajian terhadap teknologi pengolahan teh hijau Indonesia yang ada bisa 
disimpulkan bahwa untuk menghasilkan teh hijau berkatekin tinggi perlu dilakukan adalah menginaktivasi enzim polifenol oksidase. Oksidasi ini dapat dihambat atau ditiadakan apabila enzim polifenol oksidase dapat diinaktifkan secara efektif. Hasil penelitian menunjukkan bahwa penurunan jumlah katekin terbesar selama pengolahan teh hijau terjadi pada tahap pelayuan $(7,40 \%)$ serta penggilingan $(6,70 \%)$ dan terkecil pada pengeringan akhir $(1,60 \%)$ (Andi Nur Alam Syah, 2006).

\section{Prospek Teh Indonesia dan Rekayasa Produksi Minuman Fungsional Teh Kaya Katekin}

Produk pangan fungsional yang bermanfaat bagi kesehatan mulai banyak diminati oleh konsumen karena kesadaran akan pentingnya hidup sehat semakin meningkat. Salah satu jenis pangan kesehatan yang banyak dikembangkan dan diteliti adalah pangan kesehatan yang mengandung antioksidan. Mengingat peranannya yang mampu mencegah timbulnya berbagai jenis penyakit kronis maka perhatian banyak ditujukan pada upaya pancarian zat-zat antioksidan yang potensial terutama yang berasal dari tumbuh-tumbuhan. Oleh karena itu, penelitian untuk menggali lebih dalam aplikasi penggunaan teh sebagai produk minuman fungsional yang sangat bermanfaat bagi kesehatan perlu dilakukan (Puspita, 2003).

Pangan fungsional merupakan pangan alami (sebagai contoh, buah-buahan dan sayur-sayuran) atau pangan olahan yang mengandung komponen bioaktif sehingga dapat memberikan dampak positif pada fungsi metabolisme manu-sia. (Wildman, REC, 2001) Dalam dokumen konsensus "Scientific Concepts of Functional Foods in Europe" yang dikeluarkan oleh European Commission Concerted Action on Functional Food Science in Europe (FUFOSE) mendefinisikan pangan dapat dikatakan memiliki sifat fungsional jika terbukti dapat memberikan satu atau lebih manfaat terhadap target fungsi tubuh (selain fungsi gizi normalnya) dengan cara yang relevan dapat memperbaiki status kesehatan dan kebugaran serta menurunkan risiko penyakit (Diplock et al, 1999) Pangan fungsional dibedakan dari suplemen makanan atau obat berdasarkan penampakan dan pengaruhnya terhadap kesehatan. Bila fungsi obat terhadap penyakit bersifat kuratif, maka pangan fungsional lebih bersifat pencegahan terhadap penyakit.
Tanaman rempah dan obat serta jenis tanaman lainnya sudah lama dikenal mengandung komponen senyawa fitokimia yang berperan penting untuk pencegahan dan pengobatan berbagai penyakit. Salah satu contoh kandungan senyawa fungsional pada tanaman adalah katekin pada gambir dan daun teh. Pada ekstrak gambir mengandung beberapa komponen yaitu katekin 7\% sampai dengan $33 \%$, sedangkan pada daun teh kadar katekin bisa mencapai 30\% dari berat kering. Katekin yang ada pada gambir dan daun teh merupakan senyawa fungsional golongan polifenol, yang merupakan salah satu senyawa antioksidan yang berfungsi untuk melindungi tubuh dari serangan radikal bebas. Antioksidan bekerja dengan cara menekan kerusakan sel yang terjadi akibat proses oksidasi radikal bebas.

Keunggulan katekin Indonesia dijadikan suatu positioning dalam marketing untuk meningkatkan brand image teh Indonesia. Bila dilihat dari trend pasar teh hijau yang menunjukkan grafik menaik, baik dari sisi jumlah penjualan maupun merk yang beredar, tampaknya potensi ini dapat dikembangkan lebih serius. Tampaknya brand image teh hijau lebih sehat juga sudah terlanjur melekat konsumen teh Indonesia. Akan tetapi perlu juga disadari faktor rasa teh dapat juga menjadi faktor penghambat

Dari segi bahan baku, pucuk segar tanaman C. sinensis var. assamica teh Indonesia mempunyai peluang besar untuk memasok minuman fungsional. Proses pengolahan teh akan mempengaruhi keberadaan katekin dalam pucuk teh. Pada pengolahan teh hitam yang terdiri atas tahap pelayuan, penggulungan, dan oksidasi polifenol ensimatik, pengeringan, sortasi, dan pengepakan, penurunan katekin sangat nyata terjadi. Penurunan kadar katekin selama pengolahan teh hijau tidak sebanyak yang terjadi pada pengolahan teh hitam. Hal ini dimungkinkan karena sejak awal telah diupayakan inaktivasi ensim oksidasi selama proses pemanasan atau pelayuan.

Tahap berikutnya adalah penggulungan, pengeringan, sortasi, dan pengemasan. Dari kajian perubahan besarnya kadar katekin selama pengolahan teh hijau tersebut, tampak bahwa penurunan terbesar terjadi pada tahap pengeringan dan penggulungan yang akan diperparah lagi apabila inaktivasi ensim selama tahap pelayuan tidak sempurna. Upaya menyempurnakan inaktivasi ensim selama pengolahan teh hijau merupakan langkah yang perlu diambil untuk mengantarkan teh hijau 
Indonesia menjadi minuman fungsional dengan kadar katekin yang tinggi. Pengamatan terhadap beberapa produk teh hijau asal pabrik pengolahan berbahan baku pucuk teh rakyat menunjukkan bahwa kadar katekinnya lebih rendah bila dibandingkan dengan kadar katekin pucuk teh segar. Selain disebabkan oleh inaktivasi ensim yang kurang sempurna, kemungkinan besar rendahnya kadar katekin juga disebabkan mutu bahan bakunya yang kasar (daun tua).

Kadar katekin produk teh Indonesia masih dapat ditingkatkan agar lebih potensial menjadi bahan minuman fungsional. Upaya peningkatan kadar katekin pada produk teh Indonesia diharapkan dapat memacu kemajuan industri teh rakyat berbahan baku lebih baik dengan sistem pengolahan yang menjamin inaktivasi ensim yang sempurna. Sebagai minuman fungsional, teh Indonesia yang kaya katekin masih akan menghadapi kendala rasa yang kurang disukai. Teh ini memiliki rasa pahit dan sepet yang menonjol yang membedakannya dengan teh hijau Cina dan Jepang. Rasa pahit dan sepet pada teh hijau Indonesia dapat dikurangi dengan proses pemanasan seperti terjadi pada produk pengolahan teh wangi (Bambang, 1985). Oleh karena itu, walaupun kadar katekin pada teh wangi lebih rendah daripada teh hijau, pasokan katekin dari teh wangi dalam tubuh dapat ditingkatkan dengan konsumsi yang lebih banyak. Kemampuan mengkonsumsi lebih banyak teh wangi sangat dimungkinkan karena rasanya yang lebih baik daripada teh hijau (Arifin dan Bambang, 1994). Budaya minum teh wangi pada sebagian besar penduduk di Pulau Jawa dan lebih disukainya minum teh hitam di Pulau Sumatera sangat mendukung cerahnya prospek teh Indonesia menjadi minuman fungsional yang menyehatkan. Walaupun tingkat konsumsi teh di Indonesia tergolong rendah $(0,250 \mathrm{~kg}$ per kapita per tahun) dan mendapat saingan keras dari jenis minuman penyegar lain, diharapkan konsumsi teh Indonesia sebagai minuman fungsional akan meningkat pada masa mendatang.

Dengan melihat potensi bahan baku teh yang ada di Indonesia, peluang Indonesia untuk menghasilkan minuman fungsional teh kaya katekin terbuka luas. Peluang ini sudah mulai dimanfaatkan melalui rekayasa proses pengolahan teh berkatekin tinggi serta rancang bangun prototipe alat pengolahannya (Bambang dan Suhartika , 1995). Prinsip dasar rekayasa pengolahan teh berkatekin tinggi adalah proses inaktivasi enzim yang lebih baik dengan uap panas, diikuti dengan proses penggilingan yang kuat dan cepat, dan diakhiri dengan proses pengeringan berkesinambungan yang singkat. Proses demikian diharapkan dapat mempertahankan secara maksimal katekin yang dikandung pucuk teh, walaupun kenampakan teh kering konvensional (bentuk keriting terpelintir) tidak akan dijumpai.

Rekayasa produksi minuman fungsional teh kaya katekin juga dapat dilakukan melalui upaya pemuliaan tanaman dan tindakan agronomis di kebun. Perolehan klon-klon baru kaya katekin dan miskin kafein sangat mendukung keberhasilan program ini, demikian pula beberapa tindakan agronomis yang dapat memacu biosintesis katekin dan menekan produksi kafein.

\section{Rangkuman}

1. Katekin berubah menjadi theaflavin dan thearubigin ketika mengalami proses pengolahan (teh hitam) sehingga kadar katekin mengalami penurunan.

2. Katekin dipengaruhi oleh musim, ketinggian tempat, pemupukan $\mathrm{N}$, dan umur daun.

3. Sebagai penghasil produk teh berbahan baku pucuk teh varietas assamica, Indonesia berpeluang menghasilkan bahan minuman fungsional teh kaya katekin. Rekayasa proses produksi teh kaya katekin telah dan akan terus dilakukan untuk dapat merebut peluang pasar minuman fungsional. Keberhasilan rekayasa produksi minuman fungsional teh kaya katekin diharapkan dapat memacu perkembangan industri teh Indonesia pada umumnya dan industri teh rakyat pada khususnya.

\section{Daftar Pustaka}

Bambang K., dan T. Suhartika .1995. Potensi teh Indonesia ditinjau dari aspek kesehatan. Laporan Hasil Litbang Teknik Produksi dan Pasca Panen Teh dan Kina, 1994/1995.

Bambang, K. 1985. "Adsorpsi bau bunga pada pengolahan teh wangi, pengaruh tingkat penggosongan dan tingkat gulung". Tesis Program Pascasarjana Univ. Gadjah Mada

Diplock A, Aggett PJ, Ashwell M, Bornet F, Fern EB, Roberfroid MB, ed. (1999). "Scientific Concepts of Functional Foods in Europe 
Consensus Document". Brit. J. Nutr. (Cambridge: Cambridge Univ. Press) 81: pp S1-S27.

Direktorat Jenderal Tanaman Perkebunan. 2014. Statistik Perkebunan Indonesia (Teh) 20132015. Dari http://ditjenbun.pertanian.go. id. Diakses 1 Oktober 2016

Hara Y. (1999). Tea in Japan. Dalam: In Jain N.K. (ed.).Global Advances in Tea Science. Aravali Book Int'1 (P) Ltd., New Delhi. p 89-102

Hilal Y and U. Engelhardt. 2007. Characterisation of white tea-comparison to green tea and black tea. J. verbr. Lebensm 2 : 414-421.

Horic $\mathrm{H}$ and $\mathrm{K}$ Kohata. 1998. Aplication of capillary electrophoresis to tea quality estimation. J. of Chromatography. 802: 219-233.

Indarti, D. 2015. Outlook Teh. Sekretariat Jenderal Kementeriaan Pertanian Pusat Data dan Sistem Informasi Pertanian. Dari http:/ /epublikasi.setjen.pertanian.go.id/. Diakses 1 September 2016

Indonesia Investment. 2015. Teh Indonesia. Dari http:/ / www.indonesia-investments.com/ id/bisnis/komoditas/teh. Diakses 1 Oktober 2016

Karori, S. M., Wachira, F. N., Wanyoko, J. K.and Ngure, R. M.2007. Antioxidant capacity of different types of tea products. African Journal of Biotechnology, Vol.6, p.2287-96,. Dari http://www.academicjournals.org/ journal/AJB/article-full-text pdf. Diakses 8 Agustus 2016

Mahanta P.K. dan Baruah S. (1988). Flavour volatiles of assam ctc black teas manufactured from different plucking standard and orthodox teas manufactured from different altitudes of darjeerling. J. Sci. Food Agric. 45: 317-324.

Mitrowihardjo S. 2012. Kandungan katekin dan hasil pucuk beberapa klon teh (Camelia sinensis (L.) O. Kuntze) unggulan pada ketinggian yang berbeda di kebun Pagilaran. Disertasi Program Studi Pemuliaan Tanaman. Fakultas Pertanian UGM. Yogyakarta.

Nakagawa M (1970). Constituents in tea leaf and their contribution to the taste of green tea liquors. Jpn. Agric. Res. Q. , 5: 43-47.
Owour PO and Obanda M. 1995. Clonal variation individual theaflavin levels and their impact on astringency and sensory evaluations. Food Chemistry 54 : 273-277.

Pusat Penelitian Teh dan Kina Gambung (PPTK). 2006. Petunjuk Kultur Teknis Tanaman Teh Edisi 3.

Puspita. 2003. Evaluasi Kandungan Total Polifenol dan Aktifitas Antioksidan Minuman Ringan Fungsional Teh-Mengkudu Pada Berbagai Formulasi. Dari http:// mediapangan/23987/kandungantehmengk uduminumanfungsional/65\%87965.pdf. Diakses pada tanggal 8 Agustus 2015).

Santoso J., Rohayati S. dan Dadan R. (2009). Teknologi Pengolahan Produk Teh Berkatekin Tinggi. Pusat Penelitian Teh dan Kina Gambung.

Subarna, N. 1990. Analisis ekonomi pengaruh petikan halus, medium, dan kasar pada petikan rata terhadap produktivitas pemetik dan tanaman teh. Prosiding Simposium Teh V Bandung :469-479

Sud and Asha. 2000. Seasonal variations in theaflavins, thearubigins, total colour and brightness of Kangra orthodox tea (Camellia sinensis (L) $\mathrm{O}$ Kuntze) in Himachal Pradesh.. Journal of the Science of Food and Agriculture. Volume 80, P 1291-1299.

Syah A.N.A. 2006. Taklukan Penyakit dengan Teh Hijau. Penerbit Agrimedia Pustaka, Jakarta.

Takeda Y. (1994), Differences in caffeine and tannin contents between tea cultivars, and application to tea breeding. Jap. Agric. Res. Quart. 28, 117-123.

Whitehead, D. L., \& Temple, C. M. (1992). Rapid method for measuring thearubigins and theaflavins in black tea using C18 absorbent cartridges. Journal of the Science and Food Agriculture, 58:149-152.

Wildman, REC (2001). Handbook of Functional Food and Nutraceuticals. Boca Raton: CRC Press. ISBN 0-8493-8734-5.

Yamamoto, T., Juneja, L. R., Chu, D. C. \& Kim, M. (1997). Second Edition. Chemistry and Appliactions of Green Tea. New York: CRC Press 